Meta

Journal des traducteurs

Translators' Journal

\title{
Has Computerization Changed Translation?
}

\section{Brian Mossop}

Volume 51, numéro 4, décembre 2006

La traduction des noms propres (1) et Langue, traduction et mondialisation : interactions d'hier, interactions d'aujourd'hui Language, Translation and Globalization: Interactions from Yesterday, Interactions from Today (2)

URI : https://id.erudit.org/iderudit/014342ar

DOI : https://doi.org/10.7202/014342ar

Aller au sommaire du numéro

Éditeur(s)

Les Presses de l'Université de Montréal

ISSN

0026-0452 (imprimé)

1492-1421 (numérique)

Découvrir la revue

Citer cet article

Mossop, B. (2006). Has Computerization Changed Translation? Meta, 51(4), 787-805. https://doi.org/10.7202/014342ar

\section{Résumé de l'article}

Le battage entourant les technologies de l'information nous empêche de déterminer si les ordinateurs font autre chose qu'accélérer la rédaction et les recherches. Certains changements, tel l'avènement des traductions " collages "- consistant à insérer dans une traduction des suites de mots trouvées dans les traductions existantes ou dans des documents originaux en langue d'arrivée -, sont rendus possibles, certes, par les nouvelles technologies, mais ils sont pilotés par les impératifs commerciaux.
Ce document est protégé par la loi sur le droit d'auteur. L’utilisation des services d’Érudit (y compris la reproduction) est assujettie à sa politique d'utilisation que vous pouvez consulter en ligne.

https://apropos.erudit.org/fr/usagers/politique-dutilisation/ 


\title{
Has Computerization Changed Translation?
}

\author{
BRIAN MOSSOP \\ York University, Toronto, Ontario \\ brmossop@yorku.ca
}

\begin{abstract}
RÉSUMÉ
Le battage entourant les technologies de l'information nous empêche de déterminer si les ordinateurs font autre chose qu'accélérer la rédaction et les recherches. Certains changements, tel l'avènement des traductions «collages»- consistant à insérer dans une traduction des suites de mots trouvées dans les traductions existantes ou dans des documents originaux en langue d'arrivée -, sont rendus possibles, certes, par les nouvelles technologies, mais ils sont pilotés par les impératifs commerciaux.
\end{abstract}

\begin{abstract}
Because of the hype surrounding computers, it is hard to determine whether they are doing anything more than speed up the writing and research process. Changes such as the advent of 'collage' translations - where phrases are pasted into translations from old translations or original TL documents - have been enabled by technological change but they are driven by changes in the translation business.
\end{abstract}

MOTS-CLÉS/KEYWORDS

computers, 'collage' translations, technological change, translation business

\section{Discerning the new}

We live in a market society in which we are always hearing about the new and the need to keep up with the new. Large public and private bureaucracies are pervaded by rhetoric about adapting to change. There are regular announcements of new eras and new paradigms. The world, we are constantly told, has changed forever.

Most change of course is trivial, though accompanied by much hype. The question is whether, amid all the noise, we can distinguish the trivial changes - the old wine in new bottles - from the significant ones. More specifically, what is really new in the world of translation? Computerization or something else?

Why is it of interest to identify the new? In the case of Applied Translation Studies, and specifically translation pedagogy, the answer is obvious: we want to identify the (significantly) new so that we can prepare students for it. But what of Theoretical TS? I think the answer here is that the contrast between new and old affords opportunities for insight. For purposes of translation theory, we might even define the significantly new as those new things which shed light on the old. An example from interpretation: non-verbal information has always been important in oral translation, but its importance became much clearer with the advent, in the 1980s, of consecutive interpretation over the telephone, where gestures and facial expressions are of course not available to either the translator or the recipient of the translation.

A first step in identifying the new is to decide what past we will compare the present to. For the purposes of this paper, 'new' will be restricted to things that have 
become a normal feature of the commercial production of translations over the past 20 years (i.e. since the advent of personal desktop computers) and especially the past 10 years (i.e. since the advent of the World Wide Web and Internet search engines in 1993-98). In taking this approach, I leave aside the problem of different temporalities in different parts of the world: what is new in one place may be old in another. For example, in some cities, large-scale immigration is relatively recent and the need to communicate with immigrants speaking other languages is therefore new; in other cities, this phenomenon is old (i.e. more than 20 years old). In Toronto, the municipal government was producing multilingual information pamphlets for residents in the 1960s.

The dates I have chosen to define the new are marked by specific advances in information technology. Because of all the hype surrounding computers, it is tempting to divide the technological history of translation into pre- and post-computer eras. Interestingly, a frequent icon in Translation Studies publications and at translation-related websites is a reproduction of an old woodcut of a monkish figure in his cell or a Renaissance scholar at his desk with quill pen in hand, surrounded by books. However the medieval or Renaissance translator should not be lumped in with the 1970s translator armed with telephone, fax machine, IBM Selectric typewriter and regularly updated printed reference books. The 1970s translator was perhaps not as different from the present-day translator as it may at first seem. Computers have not, so far, directly affected the central translation processes of interpreting the source text and composing a wording in the target language; in the main what they seem to have done is speed up the activities of editing and research.

Another reason to be on our guard about statements concerning computers and translation is that, very often, computer-related features of the translation scene which have become fairly well established are mixed in with features which are either unusual or else mere predictions about the future. Computer hypesters and futurologists have been notoriously bad at predicting the future. ${ }^{1}$ It was not so long ago that they were predicting the arrival of the paperless office and the demise of the printed book in favour of e-books. And of course we must not forget all those breathless announcements of the imminent arrival of machine translation, beginning in the 1950 s. $^{2}$ Such announcements can still be found in computer journalism, though they finally petered out in the discourse of software companies and translation company managers in the early 1990s, to be replaced by more realistic talk about machine-aided translation. Even on the subject of machine aids, however, the crystal ball gazers do not have a very good record. Consider the following prediction recorded in the proceedings of the 7th Translating and the Computer Conference, held in London in 1985:

The advent of automatic dictation... is likely to have a major effect on translators' working methods over the medium term. These systems are developing quickly and it may well be that within five or ten years, translators will be able to 'dictate' ... to the computer rather than having to work on a keyboard. (Piggott 1986: 150)

While it is perhaps inevitable that this kind of talk occurs at meetings of translators, software makers and translation company managers, it is important that it not encroach on Translation Studies. In theoretical TS, the task is to observe and explain what is happening now or has happened in the past, not gaze into the future. 


\section{Dearth of observations of the workplace}

Unfortunately, when it comes to describing what is happening now in the world of translation, so that we can discern the genuinely new, there is a yawning gap. There are next to no observations of the translator's workplace, the place where translations are actually produced. This is so despite the shift in translation theory over the past quarter century from a focus on texts (source and translation) to a focus on the actions of the persons involved in translational communication, whether the commissioner, the recipients or (more interestingly for our purposes) the translator.

Almost all empirical studies of translation, for example, take place in vitro - at a university campus rather than in a workplace. It seems that, as of late 2003, there are only one or two published Think-Aloud studies based on research conducted in a translator's workplace (Riitta Jääskeläinen - personal communication), and no in vivo studies at all using Translog, a program which records the translator's keystrokes (Arnt Lykke Jakobsen - personal communication).

At most we have anecdotal accounts of topics such as quality control procedures, pre-editing of texts to make them easier to translate, integration of translation into the document production cycle, chunking (distributing parts of the source text among several translators), and many other topics. As a result, the following discussion of new (and old) things in the world of translation is based on personal experience and hearsay rather than on systematic documentation.

\section{Changes in translation as a business}

Most changes over the past 20 years have been changes in translation as a business. In addition to the traditional business forms (the translation department in a government or corporation; the freelance or small agency serving a local market), there are now translation companies providing service to an international clientele and dealing with remotely located translation suppliers in many countries. The very production of translations is now sometimes globalized, in the sense that a text is received for translation at one location and divided into chunks which are sent to translators in several locations around the world. ${ }^{3}$

Translation is starting to become a big business, increasingly integrating as suppliers the traditional cottage industry of freelances. The activity known as 'localization' has been added to existing translation business sectors, and it is also one of several sectors where practitioners are in the process of acquiring distinct professional status (along with court and community interpreters). That said, it nay be noted in passing that 'localization' of Web page textual content is often just a new label for an old activity, namely free translation / adaptation.

While translation has long been a business, and translations have long been commodities (things you create in order to make a living, or a profit, not just in order to convey a message), this fact has still not registered in translation theory. For example, commissioners of translations tend to be discussed as ideology bearers rather than as economic agents (paymasters). Theory has focused on the social functioning of translation in target societies and the social norms governing translation. Discussions of why a certain translation contains this rather than that wording invoke cognitive factors but hardly ever refer to workplace factors such as deadlines or chunking. The previously mentioned neglect of the workplace is unfortunate, since a closer look at 
workplaces might reveal that new work procedures accompanying the changes in translation as a business have brought about some changes in the mental process of translation production, as I will now suggest.

\section{The demand for speed and the advent of 'collage' translation}

There appears to be a demand by translation commissioners and employers for significantly increased speed in completing translation jobs. This is presumably because, in the private sector at any rate, translation can be profitable only if either wages or low or higher waged workers produce more translation per unit time. Greater speed, it is hoped, will be achieved through Internet research, archives of old translations and translation memory programs, more chunking of texts, more division of labour among translators, terminologists, documentalists, proofreaders and software engineers, and a reduction in the time allowed for quality control.

It is possible that these changes are being accompanied by two significant changes in the mental process of translation. First, when chunking is combined with division of labour and less time for quality control, the result may be that very often no one has an overview of the text as a semantic whole. Second, the advent of electronic archives of old translations, together with large corporate and government Intranets containing original TL documentation, appears to be leading to a phenomenon we might call collage translation. In collage translation, composing a translation on a blank screen is replaced by revision of old TL material from a variety of sources to make it match the source text, together with varying amounts of effort to smooth the joins between the various parts of the resulting collage. ${ }^{4}$ Thus one might find the following:

\begin{tabular}{|l|l|}
\hline French source text is a collage containing & Translator A's task is to \\
\hline $\begin{array}{l}\text { new French material (perhaps just } 20 \% \text { of } \\
\text { text) }\end{array}$ & compose own translation \\
\hline $\begin{array}{l}\text { author's modifications to an earlier version of } \\
\text { a passage which was previously translated into } \\
\text { English by Translator A }\end{array}$ & $\begin{array}{l}\text { paste in old English translation and edit it to } \\
\text { match new French }\end{array}$ \\
\hline $\begin{array}{l}\text { author's modifications to an earlier version of } \\
\text { a passage which was previously translated into } \\
\text { English by Translator B }\end{array}$ & $\begin{array}{l}\text { paste in old English translation, edit it to } \\
\text { match new French and to make Translator B's } \\
\text { choices consistent with those of Translator A }\end{array}$ \\
\hline $\begin{array}{l}\text { quotations from French documents which are } \\
\text { themselves translations from English }\end{array}$ & find and paste in original English \\
\hline $\begin{array}{l}\text { author's own translations from original } \\
\text { English documents }\end{array}$ & $\begin{array}{l}\text { find and paste in original English, and deal } \\
\text { with any mistranslations by the French writer }\end{array}$ \\
\hline $\begin{array}{l}\text { hidden quotations (no quotation marks, no } \\
\text { sources given) from database of corporate } \\
\text { documents }\end{array}$ & $\begin{array}{l}\text { find and paste in English from corporate data- } \\
\text { base, and edit to make it match the French; or } \\
\text { compose own translation }\end{array}$ \\
\hline
\end{tabular}

This way of creating translations involves a very different mental process from the traditional one of composing a translation on a blank screen. Is it a result of computerization? I suggest that the best way to answer this question is to say that the collage method of producing translations, while certainly enabled by information technology, is being driven by business pressures. 


\section{Multimedia translation and changes in the division of labour}

Multimedia translation (the integration of translated text with pictures and sound) is far from new: subtitling and dubbing of films go back to the first half of the 20th century, and before that there was song lyric translation and translations of documents containing illustrations, diagrams and the like. However, with the advent of desktop computers 20 years ago, and in particular word processors, there was a change in the division of labour. Translators of plain text were sometimes now expected to handle certain non-textual elements (notably page formatting) that had previously been handled by secretaries, editors and proofreaders. Then, after the advent of the Web, a new division of labour appeared. In the field of Web page translation, one finds IT people who are not translators performing certain tasks, translators with technical knowledge performing other tasks, and finally plain old translators who do minimal work with non-textual elements.

What is new here is not technological change per se but a change in the way humans are organized to do work. Once again, business imperatives would seem to be the key to understanding what is happening.

\section{Possible impact of voice recognition software}

Sight translation (speaking a translation of a written text) is old. It has long been done in person, or over the telephone, or as the first step in producing a written translation using a dictating machine. Now, however, a new form of sight translation may emerge if improvements can be made in voice-recognition software. While this technology does not fall within our definition of the new (as those practices which have become well established over the past 20 years), it is worth monitoring because, if it becomes established, it might bring with it a change in the mental process of translation.

With dictation, sentences had to be carefully planned in order to prevent misunderstanding by the transcriptionist as well as vast amounts of editing after the transcript was prepared. With voice-recognition software (if it can be improved), people may speak their translations in a much more spontaneous manner, because there will be no transcriptionist, and immediate on-screen editing of the result will be possible. Speaking spontaneously will probably mean more oral features in writing (e.g. more coordinate and fewer subordinate sentence structures), and it is possible that many of these will be left unedited. The final written product may thus have more oral features than traditional writing.

If such a change does occur, it would be yet another case of computers enabling change that is driven by the need of the translation business for speed (if indeed dictating proves to be faster than keyboarding).

\section{Impact of English as a global language}

Some of the changes under way in the world of translation are not related to information technology at all. An example is the impact on translation of English becoming a global auxiliary language. This development appears to be a new episode, though on a larger geographic scale, in the history of lingua francas: Latin, Russian, Mandarin Chinese and many other languages have served as auxiliary languages in culture areas 
of varying size, and have often influenced original writing in local languages, to a considerable degree through the medium of translation.

What I want to briefly consider here is whether English as a lingua franca has brought about any significant changes in translation, not into other languages, but into English itself. One thing researchers might expect to find is a reduced need for translation into English as more people speak or write in English as a Second Language, and more people are able to read or listen in English. More interestingly, as the number of non-native readers and writers grows, research might discover greater tolerance for what used to be considered poor English. This greater tolerance may not merely be making the writing of non-native writers more acceptable; it may also be influencing the output of native writers, including translators, whose revision and self-revision work is perhaps no longer always aiming at the old standard of acceptable English. (To put it in economic terms, employers and buyers of translations may be less inclined to pay for editing 'up' to the old standard.)

Another possibility is that translation into English by non-native speakers may now be increasingly valued even outside those markets where non-natives have always done most of the work (e.g. Finnish to English). The lesser quality of non-native English (in terms of the older standard) may no longer be perceived as a problem, and indeed one advantage of writing by non-native speakers may be coming into its own: non-native readers may find non-native writing easier to read because it contains less of the highly idiomatic language which is unfamiliar to the non-native reader (such as the expression 'come into its own' earlier in this sentence!). This factor could become important with all translation into English for a readership that includes many non-native speakers of that language.

\section{The view from the future}

What will future historians say about the advent of information technology in the late 20th century? Quite possibly they will decide that the impact of genetic engineering was far more important than the impact of computers. And what will historians of translation say: that the appearance of the computer and the Internet was more important than the appearance of the typewriter in the late 19th century, but less important than the appearance of the printing press in the mid-15th and far less important than the advent of writing 5000 years ago? We cannot know the answers to these questions, because the consequences of information technology, large and small, have only just begun to manifest themselves. However, we should avoid becoming too fascinated by the technologies themselves. Of more interest are the changes in the translation business. Technologies are being adopted to serve business purposes, and an offshoot of this, perhaps, is change in the mental process of translation.

\section{NOTES}

1. Aside from bad predictions, their descriptions of pre-computer days are often patently false. For example, it was and sometimes still is said that before the clickable links of the World Wide Web, reading was linear. In actual fact, there have long been non-linear genres such as dictionaries and manuals. People have never read manuals from start to finish; instead they use an index together with an elaborate system of cross-references. Indeed it has always been commonplace to read in non-linear fashion any printed book that has a table of contents or index. 
2. One subject that bears research is possible changes in users' perceptions of translation as a result of the appearance of free machine translation on Web search engines. This may be bringing about a new awareness of the difficulties of translation. Systran Software has had an MT utility available on the search engine Alta Vista since 1998, and according to Yang \& Lange (2003: 203), on one day in late 1999 there were 740,218 requests for translation.

3. If we are interested in the new, then globalization is best not defined in terms of instant international communications and capital movements, world markets for products, free trade in goods and services including cultural products, large-scale movements of peoples, or other common descriptors of globalization because these features are in fact rather old, in some cases very old. What is new in the past quarter century is cheap long-distance communications, cheap air freight, and internationalization of production: the different parts of a product like an automobile may be made in many different locations around the world.

4. The old TL material may be acquired in automated fashion using translation memory software, but this is not necessary to create a collage; translators can also manually cut \& paste existing TL material into the translation they are creating. Collage translation arises in part from collage composition by source-text writers, who 'write' parts of their reports and other documents by cutting \& pasting materials from old documents in corporate databases, then editing the result.

\section{REFERENCES}

Piggott, I. (1986): "Machine translation as an integral part of the electronic office environment," in Catriona Picken (ed), Translating and the Computer 7, London, Aslib.

YANG, J. and E. LANGe (2003): "Going live on the internet," in Harold Somers (ed), Computers and Translation: a translator's guide, Amsterdam, John Benjamins. 